\title{
Perception of Parents about the Oral Habits of their Children and their Malocclusion Traits
}

\section{María Angélica Alvarez-Páucar ${ }^{1 *}$ and Roxana Revoredo-Morote ${ }^{2}$}

${ }^{1}$ Doctor in Health Sciences, Master's in Public Health Dentistry, Paediatric Dentistry, Researcher in Paediatric Dentistry, Department of Stomatology at San Marcos University, Lima, Peru

${ }^{2}$ Master in Public Management, Orthodontist Sciences, External Assistant Researcher at San Marcos National University, Peru

*Corresponding Author: María Angélica Alvarez-Páucar, Doctor in Health Sciences, Master's in Public Health Dentistry, Paediatric Dentistry, Researcher in Paediatric Dentistry, Department of Stomatology at San Marcos University, Lima, Peru.

Received: September 16, 2019; Published: October 11, 2019

DOI: 10.31080/ASDS.2019.03.0667

\section{Abstract}

The persistent of oral habit can cause great damage to the occlusion and surrounding oral tissues during childhood. The aim of the study was to determine the relationship between the parents' perception of the their children's oral habits and their malocclusion traits in infants attending the dental clinic of San Marcos National University, in the academic period 2010. Study design: descriptive, cross-section study. The sample consisted in 50 parents and their children, whose ages were less than 47 months (less 4 years old). Methods: The data collection was obtained through a survey to parents and subsequently performed clinical examination for registration of the occlusion moments in infants. Pearson's Chi-square statistical test (SPSS 19) was applied with a significance level of 95\%. Results: Our study observed a relation between the finger sucking and midline, it was recorded that 19 infants (38\%) showed some type of digital suction (p: 0.01), as for the depth of the palate with digital suction, it was found that 11 infants (58\%) registered deep palate (p: 0.03) and within the range of age 19-36 months, all infants presented deep palate. In addition, it was found that 10 infants (53\%) presented some indication of oral breathing, and also deep palate, while only 1 infant registered normal palate (p: 0.00). Regarding the use of the bottle, 17 infants (89\%) who once consumed the bottle showed Arco de Baume Tipo II. (p: 0.03). The results suggested that early dental visit of the infants provide parents identify the main habits, such as finger sucking habit, oral breathing, use of botle and others, and therefore prevent the installation of the first features of the malocclusion in infants less 4 years old.

Keywords: Dental Occlusion; Finger Sucking, Infants; Oral Breathing; Oral Habits

\section{Introduction}

Approximately 250 million children (43\%) under five years of age in low and middle-income countries are at risk of not reaching their potential, due to the adversities they face in the initial stage of their formative years [1] this include the development of the bad oral habits that will cost cause disharmony in the oral health and because of that in the general health. The long-term follow-up of children from birth shows that the lack of growth and development of surrounding oral tissues in the first two years of life has harmful effects on health. Currently, the early care in infants is a need and it is an action feasible in our reality.

The prevalence of the bad dental occlusion in temporary or primary dentition is more than $50 \%$ worldwide and if the malocclusion persist it will influence in the permanent dentition. There are some cohort studies that had indicated that bad dental occlusion in primary dentition is the determinant of malocclusion in permanent dentition. However, it needs early management is controversial [2].

The early onset of most prevalent bad habits like thumb sucking, oral breathing, feeding bottle, biting objects, the use of the pacifier, inadecuate posture, onychophagy, tongue thrusting, are pattern learned, as they are practices or customs acquired by frequent repetition of the same action, initially conscious and then unconscious by the habituation, such as: nasal breathing, chewing, phonation and swallowing, considered physiological or functional; although there are also some non-physiological ones, thumb sucking, oral breathing, finger suction, cheilophagy and others [3].

The first signs of malocclusion are imperceptible when the function is altered and the parents contribute to the installation of oral habits by not removing them in time leading to deviations of form and function [4]. Likewise, there is a relationship between the presence of maloclussion with the type and time of breastfeeding; 
this alteration in temporary dentition are optimal occasions to diagnose and apply future early prophylactic and therapeutic measures $[5,6]$.

All these oral habits can produce dentoalveolar abnormalities, which show in lasting effects, if they do not corrections at time, they only give the transfer of habits (replacing old habits with new ones) that can be a palliative action $[4,5]$. Therefore, it should be treated with an holistic vision (speech therapist, psychologist, pediatrician and dentist). The goal of the study was to determine the relationship between the parents' perception of the their children's oral habits and their malocclusion traits in infants attending the dental clinic of San Marcos National University, in the academic period 2010, stating the type of early malocclusion, which in the future will seek to perform the interceptive treatment of this abnormally timely.

\section{Materials and Methods}

This is a descriptive and cross-sectional study. Whose sample was composed of 50 children under 47 months of age, patients who attended the Comprehensive Clinic for Children of the Faculty of Dentistry of the University of San Marcos were taken during the academic period 2010. Also, the established ethical criteria and norms were met. For the data collection, it was divided into 02 parts: the first, a structured type interview to mothers with questions related to non-nutritive sucking habits, chewing habits and functional disturbances and the second part a dental clinic where the clinical examination of possible deviations and malocclusions was recorded, according to the occlusion moments typical of the temporary dentition. For this study, the calibration corresponding to the 02 main examiners was performed. For the statistical analysis, SPSS 19 was used, using the Pearson Chi square $\mathrm{R}$ test and with a significance level of $95 \%(\mathrm{p}<0.05)$.

\section{Results}

Regarding the midline deviation, it was found that 11 infants developed this anomaly (Figure 1). When Digital Suction Habit was related to the Midline, it was recorded that 19 infants (38\%) showed some type of digital suction (p: 0.016), observing that, the age group 19-36 months, developed with more frequency deviated midline (Table 1 and Figure 2).

It was observed that 19 infants (38\%) developed some habit of digital suction, of which 11 infants (58\%) recorded deep palate (p: 0.03) (Table 2). According to the age group, it was found that, within the range of 19-36 months, all infants presented deep palate.

According to the type of breathing, it was recorded that 39 infants (78\%) obtained nasal breathing, of which 9 infants presented deep palate; however, it was found that 10 infants (53\%) presented some evidence of oral breathing, and also deep palate,

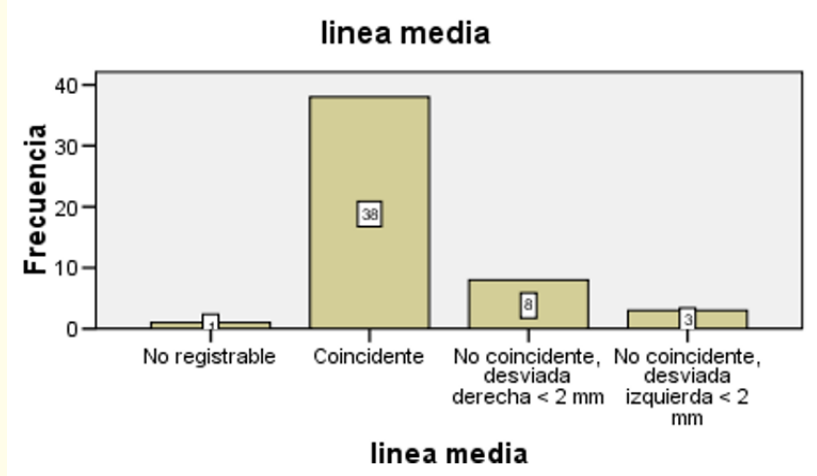

Figure 1: Midline frequency.

\begin{tabular}{|l|c|c|c|c|c|}
\hline & \multicolumn{5}{|c|}{ Digital Suction } \\
\hline \multicolumn{1}{|c|}{ Type of DMA } & No & $\begin{array}{c}\text { Almost } \\
\text { Never }\end{array}$ & $\begin{array}{c}\text { Some } \\
\text { times }\end{array}$ & Freqently & Total \\
\hline Midline & & & & & \\
ML Coincident & 25 & 0 & 11 & 2 & 38 \\
ML Not Coincidente & 6 & 4 & 1 & 0 & 11 \\
NR & 0 & 0 & 1 & 0 & 1 \\
\hline Total & 31 & 4 & 13 & 2 & 50 \\
\hline
\end{tabular}

Table 1: Relationship between Digital Suction Habit with Midline.

Intervalo de edades=19 -36 meses

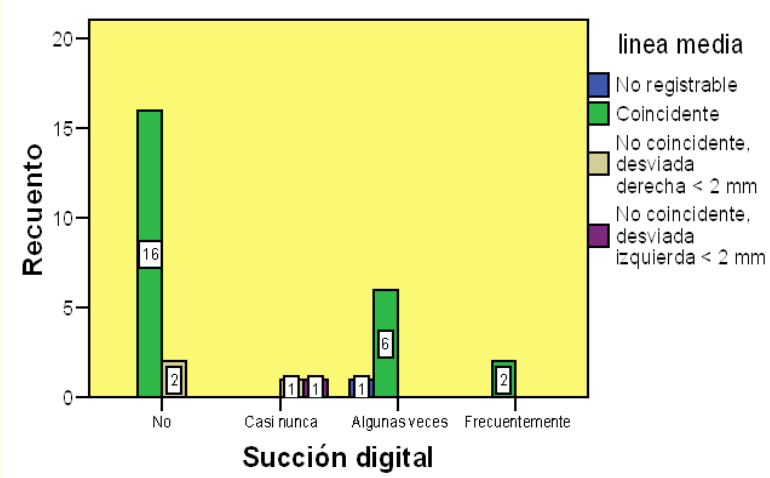

Figure 2: Frequency of Midline deviation in infants aged 19-36 months.

while only 1 infant registered normal palate (p: 0.00), observing a statistically significant relationship between deep palate and habit of oral breathing (Table 3). On the other hand, the age of the infants with the highest frequency of deep palate was the age group of 1936 months. No significant difference was found according to gender.

With regard to the consumption of bottle and type of arch, no alteration was found in the dental component, registering a Type I Baume Arch, in 23 infants (79\%) who once consumed the bottle, 
while 17 infants (89\%) who once consumed the bottle evidenced Type II Baume Arch. (p: 0.03) (Table 4).

\begin{tabular}{|l|c|c|c|c|c|}
\hline & \multicolumn{5}{|c|}{ Digital Suction } \\
\hline Type of DMA & No & $\begin{array}{c}\text { Almost } \\
\text { Never }\end{array}$ & $\begin{array}{c}\text { Some } \\
\text { times }\end{array}$ & Freqently & Total \\
\hline Palate Type & & & & & \\
Deep Palate & 8 & 4 & 6 & 1 & 19 \\
Normal Palate & 23 & 0 & 7 & 1 & 31 \\
\hline Total & 31 & 4 & 13 & 2 & 50 \\
\hline
\end{tabular}

Table 2: Relationship between Digital Suction Habit with Palate Type.

\begin{tabular}{|l|c|c|c|c|c|}
\hline & \multicolumn{5}{|c|}{ Oral Breathing } \\
\hline Type of DMA & No & $\begin{array}{c}\text { Almost } \\
\text { Never }\end{array}$ & $\begin{array}{c}\text { Some } \\
\text { times }\end{array}$ & Freqently & Total \\
\hline Palate Type & & & & & \\
Deep Palate & 9 & 0 & 7 & 3 & 19 \\
Normal Palate & 30 & 1 & 0 & 0 & 31 \\
\hline Total & 39 & 1 & 7 & 3 & 50 \\
\hline
\end{tabular}

Table 3: Relationship between Oral Breathing with Palate Type.

\begin{tabular}{|c|c|c|c|c|c|}
\hline \multirow[b]{2}{*}{ Type of DMA } & \multicolumn{5}{|c|}{ Bottle Use } \\
\hline & No & $\begin{array}{c}\text { Almost } \\
\text { Never }\end{array}$ & $\begin{array}{l}\text { Some } \\
\text { times }\end{array}$ & Freqently & Total \\
\hline Type of Arch & & & & & \\
\hline Type I Baume Arch & 6 & 3 & 3 & 17 & 29 \\
\hline Type II Baume Arch & 2 & 2 & 9 & 6 & 19 \\
\hline NR & 0 & 0 & 2 & 0 & 2 \\
\hline Total & 8 & 5 & 14 & 23 & 50 \\
\hline
\end{tabular}

Table 4: Relationship between Bottle Use with Arch Type.

Likewise, a relationship between terminal plane and digital suction was evidenced since within the age range of 19-36 months, 9 infants presented digital suction (100\%) and 8 infants (89\%) recorded a straight terminal plane or distal step. (p: 0.01).

\section{Discussion}

The habits thumb sucking, finger-sucking and others, are the most common factors influencing dental development and potentially facial growth in childhood. The relationship between oral habits and unfavourable dental and facial development is associational rather than purely cause and effect $[7,8]$.

Of the total study population, 38\% (19 infants) presented digital suction, registering permanence of the habit after 19 months (79\%), this being the most frequent non-nutritive sucking habit over mouth breathing (22\%) and the use of the pacifier. This figure on digital suction is above other previous research, ranging from $19.3 \%$ in the study conducted by Arocha., et al. [9], also the study conducted by Accardi [10], where it reflected $24.7 \%$ or the study carried out by Kashyap [11] that found an $18.9 \%$ prevalence of digital suction.

Our study also showed that the risk of deviation from the midline increases in children with non-nutritive habits coinciding with Mesquita [12], who found that using the pacifier increases the risk of midline deviation. It is known that the dentomaxillary anomalies (DMA) that produce these habits will depend on the pressure or strength, duration and frequency of the latter $[8,13,14]$. Our study found relation between finger sucking and deep palate specifically in group of 19 - 36 months or more, corroborating with some evidence that indicates changes resulting from sucking habits persist past the cessation of the habit; therefore, it has been suggested that early dental visits provide parents with anticipatory guidance to help their children stop sucking habits by age 36 months or younger [7].

This study also showed that the risk of midline deviation increases in children with non-nutritive habits according with Mesquita [12] who found pacifier sucking habit increase the risk of midline deviation. On the other hand, the frequency of oral breathing in the present work was higher (22\%), with respect to the use of pacifier (14\%), similar result obtained by the research of Accardi [10] and Murrieta-Prudena., et al. [15] where the use of the pacifier also showed a low percentage and no percentage respectively. Finding a statistically significant relationship between the different types of breathing presented and the deep palate, similar to the study conducted by Diaz [16].

According to Warren, there are significant differences in dental arch and occlusal relationships in pacifier users at 24 and 36 months compared with those that had stopped sucking by 12 months [8], a difference with our study, that did not find relation between pacifier and malocclusion traits in infants, because parents interviewed said their children did not use pacifier. Therefore, it is essential to promote more public efforts and policies related to health promotion to reduce the frequency of oral habits and malocclusions in children.

\section{Conclusion}

The results suggested that the early dental visit provides parents with early guidance to help their children stop the main habits, such as finger sucking habit, oral breathing and others to prevent dentomaxillary abnormalities, which remained between the ages of 19-36 months, showing alteration features in occlusion. 


\section{Bibliography}

1. Organización Panamericana de la Salud, Guatemala, Centro América. "Serie The Lancet sobre desarrollo infantil: Apoyando el desarrollo en la primera infancia: de la ciencia a la aplicación a gran escala". (2017).

2. Zhou Zhifei., et al. "Prevalence of and factors affecting malocclusion in primary dentition among children in XI'an, China". BMC Oral Health 16.1 (2016): 91.

3. Ricardo Manuela. "Comportamiento de escolares de primaria con hábito de succión digital luego de una intervención educativa”. MEDISAN 15.2 (2011): 222.

4. Cunha Sandra. "Hábitos Bucales" Odontopediatría en la primera infancia. Ed. María Salete Nahás P. Correa. Sao Paulo: Lavraria Santos Editora (2010).

5. Gramal Evelyn., et al. "Relación entre lactancia y maloclusiones en preescolares de 3-5 años de la parroquia Miguel Egas Cabezas-Otavalo". Odontología 17 (2015).

6. Kamdar Rajesh and Ibrahim Al-Shahrani. "Damaging Oral Habits". Journal of International Oral Health 7.4 (2015): 85-87.

7. American Academy of Pediatric Dentistry (AAPD). "Management of the Developing Dentition and Occlusion in Pediatric Dentistry". Council on Clinical Affairs (2014).

8. Majorana Alessandra., et al. "Timetable for oral prevention in childhood developing dentition and oral habits: a current opinion". Progress in Orthodontics 16 (2015): 39.

9. Arocha Alina., et al. "Maloclusiones y hábitos bucales deformantes en escolares con dentición mixta temprana". MEDISAN 20.4 (2016): 426.

10. Accardi Karla. "Prevalencia de malos hábitos orales y su asociación con anomalías dentomaxilares en niños de 3 a 6 años. Comuna Dalcahue, Chiloé. 2016". Diss. U Andrés Bello (2016).

11. Kashyap Nilotpol., et al. "Oral habits in 3 to 12 years old children: A burden on developing dentition". International Journal of Science Research 7.4 (2018).

12. Mesquita, Gabriela. "La relación entre los diferentes tipos de lactancia materna, los hábitos de succión no nutritiva y la oclusión en un grupo de niños de 3 a 6 años de edad". Diss. Universitat de Barcelona (2017).

13. Solis-Espinoza María. "Succión digital: repercusiones y tratamiento". Odontology Pediatrics 17.1 (2018): 42 -51.
14. León José., et al. "Hábitos bucales deformantes y su posible influencia sobre el plano poslácteo en niños con dentición temporal". MEDICIEGO 20.1 (2014).

15. Murrieta-Prudena José F., et al. "Frecuencia y distribución de hábitos parafuncionales en un grupo de escolares mexicanos, 2014". Revista Odontologia 11.21 (2015): 57-64.

16. Diaz Ana P. "Estudio comparativo de las características dentofaciales entre niños respiradores bucales y nasales de 8 a 12 años de edad atendidos en el Hospital Regional Docente "Las Mercedes" del distrito de Chiclayo, Región Lambayeque, en diciembre de 2016". Diss. U Alas Peruanas (2017).

\section{Volume 3 Issue 11 November 2019 \\ (C) All rights are reserved by María Angélica Alvarez- Páucar and Roxana Revoredo-Morote.}

